\title{
Social entrepreneur: same or different from the rest?
}

\begin{abstract}
A social business responds to social problems usually ignored by institutions, mobilizing resources and generating employment. To gain more knowledge about this type of enterprise, the key factors that may influence social entrepreneurship are studied and compared with nonsocial entrepreneurship. This enables advances in the scientific literature and the design of more effective policies that encourage the creation of social enterprises. To achieve this goal, after delimiting the area of study, a sample of 25,631 entrepreneurs in 59 countries was used; 9,792 of these are social entrepreneurs collected by the Global Entrepreneurship Monitor project in 2015 when a special issue focused on this topic. The results show that the majority of the factors that determine the decision to undertake nonsocial entrepreneurship also condition the individual to undertake social entrepreneurship, although the nature of their relationship or the intensity of the influence changes.
\end{abstract}

Keywords: Entrepreneurship, social entrepreneur, personality, individual variables, subjective variables. 


\section{Introduction}

In recent years, social entrepreneurship has gained importance both as a field of study and as a social phenomenon (Dacin et al. 2011). There is an increasing number of people who are aware that governments and institutions are not able to cope with different current social needs, so they decide to step forward and initiate activities that solve problems related to the survival of disadvantaged populations, to ensure a fair redistribution of scarce resources, to develop sustainable and environmentally friendly activities or to adapt technologies to local needs and infrastructures, and many other issues (Murphy and Coombes 2009; Santos 2012).

In economic, political and social terms, the interest aroused by this type of entrepreneurship has produced the implementation and development of a great variety of public policies and the emergence of associations and organizations aimed at encouraging the creation of social enterprises (Bornstein 2004; Mazzei and Roy 2017).

Although the enterprise creation process has been widely and extensively studied since the first origins of economic science, with the studies of Cantillon (1755), Say (1803) or Schumpeter (1934), it has only been recently that the creation of these particular types of enterprises, initiated and guided from their origin by a strong social mission, have been investigated; these organizations have a number of specific features that require special and differentiated attention (Austin et al. 2006). In fact, it was not until the 1990s that the real scientific breakthrough began with the first study by Greg Dees (Bornstein and Davis 2010), followed by a group of researchers who aimed to delimit the concept (Seelos and Mair 2007; Kerlin 2010), showing the main distinctive characteristics of enterprises and social entrepreneurs (Peredo and Chrisman 2006; Van Ryzin et al. 2009), highlighting the ethical aspects of such enterprises (Zahra et al. 2009; Chell et al. 2016), investigating theoretical frameworks (Meyskens et al. 2010; Santos 2012), delimiting the most suitable legal forms for 
this type of organization (Kerlin 2006; Kistruck and Beamish 2010; Bridet et al. 2018) or further developing the possible differences between social and nonsocial entrepreneurship (Austin et al. 2006; Cornelius et al. 2008; Santos 2012). Despite the large amount of research (Sassmannshausen and Volkmann 2018), the academic community has recognized that many issues regarding the process of creating and developing social enterprises are unknown, are described as an unclear field of study, and are not fully legitimized and in need of scientific contributions (Hechavarría et al. 2012).

Nevertheless, this weakness is seen as an opportunity for researchers, as there are interesting lines of research open (Mair and Martí 2006; Short et al. 2009; Pless 2012; ReyMartí et al. 2016; Sassmannshausen and Volkmann 2018). This paper aims to understand the factors involved in deciding to create a social enterprise, so the key issue to be solved is what determines the decision to start a social enterprise?

Because the literature shows that the study of the unique features of individuals who approach an entrepreneurial initiative is a key element of understanding the entrepreneurial process as a whole (Baron 2004) and is one of the lines of research still open in social entrepreneurship (Dacin et al. 2011), adopting an individual and cognitive perspective is needed to respond to the research question. This implies considering that the entrepreneur who decides to start a social enterprise will be guided by a mental process, which in turn, is influenced by his/her personality, his/her perceptions about the reality that surrounds him/her and his/her previous experiences (Baron 2004).

This paper contributes to the current literature for the following reasons. First, it cumulatively analyzes the features of individuals that affect their probability of undertaking social enterprises. Although several investigations have analyzed the influence of entrepreneurs' personal factors on the entrepreneurial process (Baron 2004; Arenius and 
Minniti 2005; García et al. 2010), previous empirical literature paid little attention to these variables from the social field (Van Ryzin et al. 2009; Zebeda 2012).

Second, because this analysis is replicated in a sample of nonsocial entrepreneurs, the comparison of the results will clarify the current extensive debate on whether or not social entrepreneurship should be dealt with as a specific type of entrepreneurship (Acs et al. 2013), or on the contrary, if we are faced with a particular type of entrepreneurship that, due to its singularity, should be analyzed separately (Austin et al. 2006; Bornstein and Davis 2010).

Finally, this quantitative perspective allows us to legitimize social entrepreneurship as a field of study because, in spite of the large number of current papers, there is still much to be done since most research is based on theoretical reviews or case studies; these are an adequate methodology for the first stages of the study of a phenomenon, but they need to be complemented by quantitative studies with large samples in order to achieve more generalizable results that represent important scientific advances (Short et al. 2009; Dees 2012; Hockerts 2015; Terjesen et al. 2016; Sassmannshausen and Volkmann 2018).

The results show that the majority of the factors that lead to the decision to undertake nonsocial enterprises also condition individuals to undertake social enterprises, although the nature of the relationship or the intensity of the influence changes. The social entrepreneur profile is a male of any age who has studies at a university, who is more likely to undertake a social enterprise the less developed the country is, who knows other entrepreneurs, and who perceives business opportunities, feels capable of creating an enterprise and is not afraid of failure. In contrast, the nonsocial entrepreneur is a young male who has studied at a university, who is more likely to undertake entrepreneurship in more developed countries, who perceives business opportunities, who feels self-efficient, who has a low level fear of failure and knows other entrepreneurs. 
To achieve the objectives, the paper is structured as follows. First, the influence of cognitive variables and the socialization variable on the process of creating enterprises is analyzed, focusing on the case of social entrepreneurship. The different hypotheses proposed in the research are derived from this review. Next, these hypotheses are contrasted with a sample of 25,631 entrepreneurs from 59 countries; 9,792 are social entrepreneurs. The paper concludes with a discussion of the results and an analysis of the implications they have for research as well as for companies and administration at a practical level.

\section{Delimitation of the concept of social entrepreneur}

There are people behind every business initiative who, by distributing economic resources, manage to create value by discovering new markets, by creating alternative ways of doing things, and by seeking change and opportunities offered by the market (Dees 2001). The creation of new enterprises ultimately depends on the actions carried out by these people who are called entrepreneurs.

Thus, Dees' (1998) work is based on the history of entrepreneurship literature and analyzes the fact that social entrepreneurs are first and foremost a type of entrepreneur. From this analysis, it is clear that the social entrepreneur adopts the element of value creation and Schumpeter's (1934).notions of innovation and change. Therefore, Dees complements the proposals made by authors such as Drucker (1989) and Stevenson et al. (1989). In particular, Drucker (1989) extends the concept developed by classical authors, emphasizing that, to start a business activity, it is essential for entrepreneurs to recognize and take advantage of the opportunities observed in their environment. Stevenson et al. (1989) confirm the statement made by Drucker (1989) about the entrepreneur and add the concept of ingenuity. With this, the authors oppose the idea that there are resource limitations when launching a business activity (Peredo and McLean 2006). 
Therefore, any type of entrepreneur is a person that, after identifying an opportunity in the market, decides to create an enterprise with the objective of taking ownership of the income it generates in a creative or novel way (Shumpeter 1934; Kirzner 1973; Morris 1998; Sharma and Chrisman 1999; Shane and Venkataraman 2000). Nevertheless, the social entrepreneur is even more (Nicolás y Rubio 2016).

Based on the analysis, it appears that, in the beginning, the concept of social entrepreneur that predominated was that of a person who does not seek personal economic compensation but instead seeks to create social value (Boschee 1998; Bornstein 1998; Thompson 2000; Boschee and McClurg 2003; Hibbert et al. 2005). However, with time, it is possible to find an increasing number of definitions in which these entrepreneurs give rise to economic retributions both for society and for themselves (Light 2006; Zhara et al. 2009).

In addition, a consensus in all of these definitions is observed; social entrepreneurs start with an explicit social mission in mind; their goal is to make the world a better place (Dees 1998; Nissan et al. 2012). Therefore, the measure of their success is not the amount of economic benefit they achieve but the extent to which they create social value.

Social entrepreneurs use business management tools, participating in a continuous process of innovation, adaptability and learning, with which they achieve their much needed social value (Dees 2001; Zhara et al. 2009; Santos 2012), satisfying niches ignored by the government and public institutions (Thompson et al. 2000; Santos 2012).

In short, the ideas of the social entrepreneur tend to change the future, making the current world a better place for everyone. Therefore, it is not surprising that authors such as Murphy and Coombes (2009) state that social entrepreneurs begin by discovering new means of achieving constructive social change. In order to accomplish this, they show balanced judgment and a coherent unity of purposes and actions in the face of social complexity (Mort et al. 2003). Hence, we find statements, such as those by Bill Drayton, the founder of Ashoka: 
"Social entrepreneurs are not satisfied with distributing fish, not even teaching how to fish. They will not rest until they revolutionize the fishing industry”.

After reviewing the literature, it has been concluded that the social entrepreneur is the person who initiates an innovative business activity with the main objective of accomplishing a social or environmental good for a community, perceiving a neglected social problem as a business opportunity with the aim of solving it, although pursuing this purpose does not imply not obtaining an economic benefit.

\section{Key factors to become an entrepreneur}

The factors that influence the decision to start an enterprise do not have to be different in the case of the social entrepreneur (Acs and Audretsch 2001). Starting a new business, and even its success, depends as much on external and uncontrollable constraints, such as culture, education, technology, social norms, government policies, etc. (Langowitz and Minniti 2007), as on variables related to certain innate features of the entrepreneur as well as factors related to personality, perceived abilities or previous life experiences (Arenius and Minniti 2005).

Based on this perspective, the creation of new organizations is believed to depend ultimately on entrepreneurs' behavior; therefore, the study of the entrepreneur's distinctive attributes is a key aspect of understanding the business creation process as a whole (Baron 2004). In particular, researchers point out that the decision to create a company is guided by the mental processes by which the individual acquires, stores, transforms and uses the information received from the environment (Baron 2004). This would explain why some people are able to see opportunities, begin to put an idea into practice and even become successful.

The study of entrepreneurs' unique qualities, abilities or skills that lead them to implement the decision to create a company has focused on the analysis of many variables 
(McClelland 1961; 1987; Hornaday and Aboud 1971; Timmons 1978; Brockhaus 1982; Begley and Boyd 1987; Solomon and Wislow 1988; Chen et al. 1998; Shane and Venkataraman 2000; Mueller and Thomas 2001; Jiménez et al. 2015). This paper will focus on the analysis of the three variables through which the Global Entrepreneurship Monitor (GEM) framework supports its individual perspective (Singer et al. 2015): the perception of good opportunities, the belief that they have the skills and knowledge related to the creation of enterprises and the degree to which the entrepreneur is afraid of failure. In addition, these three variables are complemented by the study of a fourth variable, socialization. Individuals who have experienced examples of entrepreneurs close to them during their lifetime are considered more likely to transform ideas into real enterprises (Berger and Luckman 1984; Light and Rosenstein 1995; Starr and Fondas 1992; Formichella 2004).

\section{Perception of opportunities}

Perceiving opportunities is a process that depends directly on the individual's ability to detect unexplored gaps or niches under dynamic, creative and reflective processes (Baron 2004; Zander 2004). Entrepreneurs are often characterized by a strong intuition identifying profitable business opportunities and usually support their ideas in anticipation of other market players (Baron 2004).

The social entrepreneur finds opportunities in places where the nonsocial entrepreneur is probably only perceiving problems. Health, education, poverty, hunger or environmental problems, such as energy, water and global warming, are problems that nevertheless become sources of opportunities for social entrepreneurship (Neck et al. 2009). There are authors, such as Austin et al. (2006), who state that it is even easier to perceive opportunities in the social arena than in the nonsocial arena, probably because the opportunities in this sector are easily observed by watching the news, reading the press or walking in any city, where our 
environments are overwhelmed by neglected social problems. If an enterprise were created for each social problem, there would probably be more social than nonsocial enterprises. However, this does not happen because many social problems are not perceived as feasible opportunities for creating an enterprise. Moreover, the literature mentions that the rate of social entrepreneurship is lower than it should be, first, because individuals perceive that social problems are complex, otherwise they would probably not exist, and multidimensional (Weerawardena and Mort 2006). Multidimensionality makes solving social problems require highly innovative approaches, which can make entrepreneurs indecisive about starting their own business, as they are not clear about the most efficient way to solve the problem (Weerawardena and Mort 2006).

Second, the so-called proactivity is also considered a key factor when the entrepreneur perceives a business opportunity as feasible (Bojica et al. 2012). In particular, it has been stated that proactivity is the entrepreneur's ability to identify urgent problems in society (Lumpkin 2011). The fact that an entrepreneur is proactive could be a double-edged sword. When the number of social problems is high, a moral dilemma can arise within the individual when deciding which social opportunities to pursue first and which to avoid at the moment of starting the social activity.

Third, the social entrepreneur's autonomy changes depending on the type of opportunity. Although there are social opportunities that can be exploited by social businesses with total independence, at other times, however, their nature requires entrepreneurs to collaborate with stakeholders, public agencies, other companies and the disadvantaged population on which they focused, among others; therefore, they have a mixed autonomy, according to the literature (Lumpkin 2011). If an individual has to collaborate and therefore depend on other entities that may not be as interested in his/her motive to operate the social 
enterprise, he/she will probably not perceive the social problem as a feasible business opportunity.

In short, it can be understood that social entrepreneurs, like any type of entrepreneur, identify opportunities in their environment and perform accordingly. However, in their case, the founding purpose of the company is inherently linked to a solution to problems in the population and the planet. Therefore, these problems will be related to a lack of natural resources, an increase in environmental challenges and new innovative technologies, such as clean technology, which are problems any observer is aware of (Neck et al. 2009). However, it should be considered that not all individuals who perceive social problems will become social entrepreneurs; only those who are capable of perceiving social problems as business opportunities with which to create an enterprise and solve the social problem will finally become social entrepreneurs.

Therefore, we can advance the following argument:

Hypothesis 1: Individuals with high levels of perception of opportunities are more likely to be social entrepreneurs.

\section{Perceived self-efficacy}

Based on the analysis of the factors that, from the individual point of view, favors the intention to create an enterprise, some research reveals the importance of the entrepreneur having not only the required skills and abilities but also his/her perception (Bandura 1997). This variable is called perceived self-efficacy in the literature. The study of the concept of self-efficacy begins with the discussion of cognitive social theory. In the theory itself, the concept of self-efficacy is delimited; it is understood as that "belief in one's own abilities to organize and implement the required courses of action that will produce certain achievements 
or results” (Bandura 1997), considering it a key variable when controlling certain external elements of the entrepreneur.

Perceived self-efficacy has its origin in the entrepreneur's self-concept, and therefore, it does not reflect a real situation but a person's perception of whether he/she has the required skills and if he/she is able to use those skills to achieve a desired result (Boyd and Vozikis 1994). This is so because feeling that one has the technical skills required to start and maintain an enterprise provides the entrepreneur with the proper attitude to start a business and even favors the recognition of business opportunities (Boyd and Vozikis 1994).

Becoming a social entrepreneur figure, like any type of entrepreneur, involves paying attention not only to his/her abilities but also to the individual's perception of them (García et al. 2010).

In this sense, the fact that the social entrepreneur is often possessed by the idea of making the world a better place for everybody, sometimes performing in truly adverse situations characterized by a lack of resources and high uncertainty, suggests that the perception they have of their abilities is greater than that of other entrepreneurs. If nonsocial entrepreneurs' behavior is analyzed, it is observed that they usually perform under a rational prism, trying to maximize their benefits and minimize their costs and not hesitating to conclude their activities if a lack of resources or poor access to them leads to incurring losses (Dees 2001).

However, this situation of poor access or a lack of resources is quite common in the social sector, which seldom prevents the entrepreneur from intending to start his business. The individual who decides to pursue an approach, which involves the solution to a social problem, usually continues his activities, thinking that he is able to do more with less by using scarce resources efficiently and exploring all the options to obtain them, from pure philanthropy to trading methods of the business sector (Dees 2001). 
This higher perceived self-efficacy is also confirmed in research that claims that entrepreneurs' confidence in their own skills, knowledge and ability to start a new business increases when the entrepreneur is in a state of alert (Langowitz and Minniti 2007). This state of alert has especially increased in the last decades, due to greater access to information, the decline of services provided by the welfare state, and the insufficient involvement of public institutions in social problems. This has, without a doubt, promoted the development of projects that aim at ending social marginalization or inequality, as well as trying to improve living conditions, working conditions or relationships between people. A state of alertness and social concern in the entrepreneur should have been produced prior to this. This state of alert, in turn, has generated an increase in entrepreneurs self-perceptions, considering themselves able to fulfill their objectives successfully (Langowitz and Minniti 2007).

Based on this, the following hypothesis is proposed:

Hypothesis 2: Individuals with high levels of perceived self-efficacy are more likely to be social entrepreneurs.

\section{Fear of failure}

When discussing the entrepreneur's individual variables, it should be taken into account that the decision to start a business activity exposes the individual to the uncertainty surrounding the business idea. If the entrepreneur is afraid and perceives that the possibility of creating a business is too risky, he will not get involved in that venture (Arenius and Minniti 2005). In the literature, regarding the fear of failure variable and social entrepreneurship, it is stated that the social entrepreneur works in risky conditions in his/her everyday life, just as all entrepreneurs do (Leadbeater 1997; Dees 2001; Mort et al. 2003; Weerawardena and Mort 2006; Peredo and Chrisman 2006; Shaw and Carter 2007; Zahra et al. 2009; Di Domenico et al. 2010; Lumpkin 2011) 
The social entrepreneur must adapt the demand to the supply of goods and services, like any other entrepreneur, while taking into account all the risks involved in carrying out this activity (Knight 1921). They must be able to bear uncertainty and risk when starting a business to become an entrepreneur (Parker 2009). Regarding the specific case of the social entrepreneur, taking risks is a key feature recognized in the social enterprise literature (Leadbeater 1997; Peredo and Chrisman 2006; Zahra et al. 2009). This is so because the social enterprise is created with the aim of overcoming multiple challenges to solve neglected social problems, such as being able to mobilize resources or its own location in markets that do not work well (Weerawardena and Mort 2006).

However, due to the characteristics of social entrepreneurship, some authors have come to differentiate between different degrees of risk assumption by the social enterprise when trying to access resources and financing (Lumpkin 2011). On the one hand, authors state that individual donors can encourage the organization to make risky decisions since they only think of solving social problems that motivated them to donate resources to the company, while the donors (foundations, government agencies, banks, etc.) demand less risk tolerance for the business organization since their aim is to help them achieve their goal, and therefore, they are also interested in the long-term continuity of the enterprise.

On the other hand, as the social enterprise's nonmonetary resources, such as voluntary resources and in-kind contributions, are not considered resources for nonsocial enterprises, it is said that they could alter business processes in the social context. Although the social entrepreneurship literature discusses this fact, it has not been empirically tested yet (Lumpkin 2011).

Finally, the literature claims that because social entrepreneurs are financed with resources that are not common for all types of enterprises, such as those mentioned above, this automatically leads to lower levels of fear of failure on the part of the social entrepreneur. 
This is so because the resources used for the company's survival and performance do not have to belong to the social entrepreneur's personal or family assets (Weerawardena and Mort 2006; Shaw and Carter 2007; Lumpkin 2011) and because the social entrepreneur does not have to return most of them to the people or entities that donated them to the social enterprise.

However, at this point, some clarification is needed. It is true that, in social entrepreneurship, personal and familial financial resources are used less often for funding (Shaw and Carter 2007), which would reduce the levels of fear of failure of the social entrepreneur. However, in order to obtain voluntary resources or contributions from donors, it is essential for the entrepreneur to have certain personal features, such as a strong reputation and integrity (Leadbeater 1997). Therefore, it has been stated that social entrepreneurs experience less financial risk than nonsocial entrepreneurs, but instead, when revealing their personal characteristics to attract their main funding resources, they experience greater personal risk, such as losing their credibility at the local level and their network of personal relationships (Ripolles and Blesa 2006). Therefore, it is a mistake to think that being a social entrepreneur necessarily implies assuming less risk than being a nonsocial entrepreneur. Furthermore, the literature states that social entrepreneurs face a specific set of challenges because they deliberately locate their activities in areas where markets work poorly (Di Domenico et al. 2010). Even so, the social entrepreneur does not allow fear to keep him/her from pursuing his/her vision; social entrepreneurs assume calculated risks and manage downside risk in order to reduce losses derived from failure (Dees 2001). Despite the social entrepreneur's proximity to risk and failure, he understands the importance of his actions and, therefore, observes the risk tolerance for stakeholders and uses this to diversify the risk of those who are better prepared to accept it (Dees 2001).

Based on this, the following hypothesis is proposed: 
Hypothesis 3: Individuals with low levels of fear of failure are more likely to be social entrepreneurs.

\section{Socialization}

Socialization is an essentially a spontaneous process. It is usually latent due to the absorption of actions and behavior coming from an individual's contacts (De la Rosa Acosta 1986; Starr and Fondas 1992; Oetting and Donnermeyer 1998; Grusec and Hastings 2014). The socialization process does not only involve receiving orders, warnings and explicit instructions from older and more experienced population; it is also related to the perception of the forms of behavior of the people surrounding the individual.

The relationship between socialization and entrepreneurship is based on the fact that the people who the individual has had contact with and their life experiences influence the decision to create an enterprise (Starr and Fondas 1992; Light and Rosenstein 1995; Stevenson 2000). In particular, if an individual has experienced close examples of people who started or conducted a business, he/she is considered more likely to have an entrepreneurial attitude.

It is possible to find two different stages in the socialization process (Berger and Luckman 1984). First, primary socialization takes place, which begins in the first years of life and comes from the first people who have contact with the individual, usually their family. Children in their childhood receive a limited image of reality and believe that this is how it truly is, receiving their elders' attitudes and behaviors, which are their responses determined by lived experiences. This is how each person begins to write his/her own story (Berger and Luckman 1984; Oetting and Donnermeyer 1998; Grusec and Hastings 2014).

Secondary socialization begins throughout the years. In particular, it is developed when individuals, still in their childhood, begin to interact with people outside their family, 
when they begin to engage in social institutions such as school, the neighborhood or playgrounds (Berger and Luckman 1984; Oetting and Donnermeyer 1998; Formichella 2004; Grusec and Hastings 2014). In this new life setting, individuals find themselves with another reality that is different from the one lived before that moment. When they realize that the world is much more than their home and family, they acquire a broader vision (Berger and Luckman 1984; Oetting and Donnermeyer 1998; Formichella 2004; Grusec and Hastings 2014). Becoming a member of society allows individuals to find new forms of behavior and rules of coexistence, which will undoubtedly determine their personal and working future (Berger and Luckman 1984).

Therefore, socialization facilitates the individual's development by enhancing, atrophying or complementing the innate features of each person (Berger and Luckman 1984; Starr and Fondas 1992; Formichella 2004; Grusec and Hastings 2014). This suggests that those individuals who in their lives have been able to observe and learn attitudes from an entrepreneur, such as searching for alternative paths, taking risks, taking advantage of opportunities, thinking innovative ideas, being perceptive and motivated are more likely to start business activities (Berger and Luckman 1984; Light and Rosenstein 1995; Starr and Fondas 1992; Formichella 2004).

Taking this argument into account, it is logical to think about the key role that having at some point in their lives met an entrepreneur and having been able to observe and learn about the search for alternative paths, risk-taking, and many other issues could have for social entrepreneurship.

Based on this, the following hypothesis is proposed:

Hypothesis 4: Individuals who have met somebody who has created an enterprise are more likely to be social entrepreneurs. 
Figure I summarizes the hypotheses of this study. The tendency to become a social entrepreneur is particularly influenced by the perceived level of business opportunities, by the very concept one has about one's own abilities, by the level of fear of failure and by the fact that the individual knows other entrepreneurs. In addition, four control variables are included in the model: gender, age, education level and level of development of the country.

\section{(INSERT HERE Figure I)}

\section{Methodology}

\section{Sample and data collection}

In this paper, the individual is the unit of analysis; the data collected by the GEM project in 2015 is analyzed; 2015 was the year in which a special section was devoted to the study of the social entrepreneur. The GEM Project arises from the need to fill in the gap caused by the lack of information regarding entrepreneurship at a time when governments in developed countries understand that the figure of the entrepreneur is the key to mitigating the effects that are taking place in labor markets as a consequence of the country's own development. The GEM aims to facilitate the comparison of entrepreneurial activity between countries, and for this, it uses the same measurement system in all the territories that participate in the study (Reynolds et al. 2005).

Authors such as Hindle (2006) argue that before the emergence of the GEM the majority of studies on economic development focused on the analysis of established companies, the sector with the highest status in the economy. The value of emerging companies was not included in most attempts to record economic performance. The GEM allows for the analysis of the factors that affect the sector of newly created companies in particular. In fact, it has 
been stated that the GEM project is one of the most significant advances in the study of the business creation process (De Castro et al. 2008).

In addition, currently, and during its 17 years of results, it has been the only source of comparable data that exists worldwide on a wide range of variables associated with entrepreneurial activity and the different stages that make up its development. The great scientific basis and robustness of this database has resulted in using it for this study (De Castro et al. 2008).

The data were collected by telephone or face-to-face interviews using a standardized questionnaire. A representative adult sample (18-64 years) from 59 countries was used, resulting in a total of approximately 181,281 people interviewed, although only 142,690 were valid for our study.

To ensure that the respondents reflect the established population correctly, the GEM assigned a gender-sensitive and age-sensitive weighting factor to each respondent. In particular, the age and gender distribution of the samples were compared with the 2002 US Census International Database. Thus, the weights were calculated to match the sample from this standard source of population structure estimates. For more information on the GEM and its methodology refer to Reynolds et al. (2005).

\section{Measure of the variables}

To test the hypotheses, 2 dependent variables, 4 independent variables and 4 control variables were used.

\section{Dependent variables}

To identify the individuals involved in the business creation process, respondents were asked if they were currently trying to start a new business, alone or with other people, including 
being self-employed, and whether they were selling any goods or services to others. As a result, a dichotomous variable was constituted, where (1) were classified as those individuals who answered positively, and (0) were those who answered negatively. The variable was created with two values corresponding to each type of response: being an entrepreneur and not being an entrepreneur. To identify the individuals in the process of creating a social enterprise, they were then asked if their activity, organization or initiative had social or environmental objectives or if it sought the well-being of the community. A new dichotomous variable was created with the results, which were classified as (0), those who answered no, and (1), those who answered yes.

\section{Independent variables}

The data on perceived opportunities, perceived self-efficacy, fear of failure and socialization, collected by the GEM Project basically cover 4 questions: 1) Do you think that there are good opportunities to start a business in the area where you have lived in the six months prior to the survey? 2) Do you believe that you have the sufficient knowledge, skills and experience to start a new business? 3) Does fear of failure prevent you from starting a business? and 4) Have you met someone who started a business in the last two years? This enables us to create four dichotomous variables with value (1), when the respondent answers yes, and with value (0) otherwise.

\section{Control variables}

After reviewing the literature, four control variables that the literature recognizes can condition the decision to start a business were included: age, gender, education level (Peterman and Kennedy 2003) and level of development (Rivera-Santos et al. 2015; Dichon and Ghore 2016; Nicolás et al. 2018). The first one was measured by a variable of three 
categories. In the first category (0), there are individuals between the ages of 18 and 34; in the second category (1), they are between 35 and 54; and in the third category between 55 and 64 . In addition, gender was measured using a dichotomous variable, where men were classified with (0) and women with (1). The education variable was grouped into three categories, where (0) classified individuals with primary studies, (1) with secondary studies and (2) with higher or university education. Finally, the level of development was grouped by a variable of three categories, where underdeveloped countries were classified with (0), developing countries with (1) and developed countries with (2). The classification of economies by economic development level is adapted from the World Economic Forum (WEF). According to the WEF's classification, in underdeveloped countries, subsistence agriculture and extraction businesses predominate, and there is a heavy reliance on (unskilled) labor and natural resources. In developing countries, the economy has become more competitive with further development accompanied by industrialization and an increased reliance on economies of scale, with large, capital-intensive organizations being more predominant. In addition, in developed countries, as development progresses toward innovation, companies develop more knowledge, and the service sector expands (http://weforum.org). Table I specifically shows the countries that are included in each of the 3 groups of countries at different development stages.

(INSERT HERE Table I)

\section{Model specification}

As shown, many of the independent variables are dichotomous and so are the dependent variables. This fact leads to confirming the hypotheses proposed through the technique of binomial logistic regression analysis. This technique enables us to work with dichotomous dependent variables, as in discriminant analysis but adds the possibility of using dichotomous 
and continuous independent variables within the model simultaneously. One of the advantages binomial logistic regression analysis has over discriminant analysis is that it is not affected by the problems that arise when there is heteroscedasticity or the data do not follow a normal distribution (Kerlinger 2002).

The dichotomous variable can take the value (1) if the event occurs (having started a social enterprise) and (0) if the event analyzed does not occur. Within this binomial process, there is a probability of the success of the event occurring, which is represented by p, and a probability of failure represented by q. Thus, the logistic regression model can be represented as follows: Logist $(\mathrm{P})=(\mathrm{p} /(1-\mathrm{p}))$. In the logistic regression analysis, a theoretical model or linear combination of variables with empirically determined weights is obtained (Hair et al. 1998). The logistic regression model has a similar structure to the multiple regression of ordinary least squares model, and it represents a single multivariate relationship with coefficients that show the relative weight of each independent variable. A positive coefficient would increase the probability of the event occurring, whereas a negative coefficient would decrease it.

To confirm the significance of the individual regression coefficients, the Wald test was used. In addition, in order to interpret the results more easily, the odds-ratio (OR) was also used for each of the predictor variables. The OR is the exponent of the regression coefficient. Specifically, for binary variables that approximate the most likely (or improbable) amount, it is the result of being present among respondents with a predictor value equal to one, compared to respondents with a predictor value of zero. From that, it can be inferred that a $\beta \mathrm{i}$ coefficient close to zero, i.e., an odds-ratio close to 1 , will indicate that changes in the associated independent variable will have no effect on the dependent variable Y.

\section{Results}


Table II shows the correlations of the variables under study. Table III shows the results obtained in the two models estimated by logistic regression for the case of the creation of social enterprises and nonsocial entrepreneurs. To evaluate the model goodness-of-fit, we present the pseudo-R2, known as the McFadden's likelihood-ratio index, since the standard coefficient of determination commonly used in ordinary least squares regressions is not appropriate for use with the logistic models. The pseudo-R2 values are low, 0.1639 in the case of commercial entrepreneurs and 0.0853 for social entrepreneurs. These low values, especially in the model for social entrepreneurs, show that a more in depth study of the factors that explain the differential behavior of social entrepreneurs is needed. Most likely, the next step could be to include specific variables that affect only social entrepreneurs, going beyond the comparison with the commercial entrepreneurs that we performed in our analysis. Model I corresponds to nonsocial entrepreneurship, while model II corresponds to social entrepreneurship. Table III shows estimated logistic regression models in order to observe the influence of the explanatory variables proposed on becoming a social and nonsocial entrepreneur under ceteris paribus. That is, the impact of each of the proposed variables on both types of entrepreneurs is analyzed, but the effect of the other variables was controlled.

In addition to some common diagnostic indicators, which are useful for comparisons within the same model and comparisons based on incorporated variables, the table provides information regarding the validation of the models by examining their validity. In particular, the goodness of fit test of Hosmer and Lemeshow is performed to confirm its degree of calibration; this information is complemented with the percentage of correct predictions.

(INSERT HERE Table II and Table III)

Note that the results show that high levels of significance are obtained in all the analyzed variables of both models. 
To start, the results of model I will be analyzed, which were prepared with the sample of nonsocial entrepreneurs. Regarding the control variables, it is observed that gender has obtained negative results, which indicates that men have a greater probability of becoming nonsocial entrepreneurs (OR 0.903). Regarding the education level variable, it is found that individuals who have primary and university studies have a positive relationship with becoming a nonsocial entrepreneur. The results specifically indicate that, compared with individuals with a secondary education, those who have completed primary school (OR 1.074) and university studies (OR 1.124) have a higher probability of becoming nonsocial entrepreneurs. Regarding the age variable, younger individuals are identified as having a higher probability of creating a nonsocial enterprise. In fact, when comparing individuals between the ages of 35 and 64 with those between the ages of 18 and 34, it is observed how the latter have obtained positive results (OR 1.084) regarding undertaking nonsocial enterprises, while those between the ages of 55 and 64 show a negative relationship (OR 0.540). To conclude with the control variables, when taking underdeveloped countries as a reference, the results obtained regarding the level of development variable show that individuals in developing countries have a higher probability of undertaking nonsocial enterprises (OR 1.084), whereas in the case of developed countries, this figure is negative, which shows that individuals of less developed countries have a higher probability (OR 0.541) of creating a nonsocial enterprises than those of developed countries.

Regarding the independent variables, perception of opportunities shows a positive relationship with the dependent variable. In addition, its OR (1.724) indicates that individuals who perceive opportunities are almost twice as likely to become a nonsocial entrepreneur. On the other hand, the perceived self-efficacy variable has also obtained positive results in relation to the dependent variable. Specifically, it is observed that individuals who feel capable are 4.551 times more likely to become nonsocial entrepreneurs than those individuals 
who doubt their abilities. In contrast, the fear of failure variable shows a negative relationship with the creation of a nonsocial enterprise, which indicates that people who are afraid of possible failure will have a lower probability of becoming a nonsocial entrepreneur (OR 0.695). Finally, the socialization variable has a positive relationship with becoming a nonsocial entrepreneur. In particular, the data indicate that people who know other entrepreneurs are 2.161 times more likely to become nonsocial entrepreneurs.

Next, the results obtained for Model II, which is made with the sample of social entrepreneurs, will be analyzed. Starting with the control variables, regarding gender, it is observed that men have a greater probability of becoming social entrepreneurs (OR 0.892). On the other hand, education level variable demonstrates that both individuals with a primary education and a university education show a positive relationship with the dependent variable. These results indicate that individuals with a primary education (OR 1.072) or university education (OR 1.790) are more likely to become social entrepreneurs than those with a secondary education. On the other hand, regarding the age variable, it is confirmed that none of the age groups studied have obtained significant results; therefore, it is demonstrated that individuals of all ages undertake social enterprises equally. Finally, to conclude with the control variables, the results obtained for the level of development variable are analyzed. It is observed that as the level of development increases the probability of the individual becoming a social entrepreneur decreases. Specifically, it is confirmed that, compared to underdeveloped countries, developing countries (OR 0.651) and developed countries (OR 0.501) have demonstrated negative results in regard to becoming a social entrepreneur.

Once the results of the control variables are analyzed, the results of the individual variables will be discussed. Starting with the variable of perception of opportunities (hypothesis 1: Individuals with high levels of perception of opportunities are more likely to be social entrepreneurs), it is observed that it has a positive relationship with becoming a social 
entrepreneur. In particular, it is seen that individuals who perceive opportunities are 1.755 times more likely to become entrepreneurs than individuals who do not perceive opportunities. In addition, regarding the variable of perceived self-efficacy (hypothesis 2: Individuals with high levels of perceived self-efficacy are more likely to be social entrepreneurs), it is observed that it also has a positive relationship with the dependent variable. In addition, it is confirmed that individuals who perceive that they are capable are twice as likely (OR 2.075) to become social entrepreneurs than those who do not feel capable. Regarding the variable of fear of failure (hypothesis 3: Individuals with low levels of fear of failure are more likely to be social entrepreneurs), the negative relationship it has with the dependent variable shows that individuals who afraid of a probable failure are less likely to become social entrepreneurs (OR 0.809). To conclude with the independent variables, an analysis is made of the socialization variable (hypothesis 4: Individuals who have met somebody who has created an enterprise are more likely to be social entrepreneurs). Regarding this variable, it is observed that knowing another entrepreneur has a positive effect in regard to the individual deciding to undertake a social enterprise. This fact in particular makes it almost twice as likely (OR 1.900) for these individuals to undertake a social enterprise.

Therefore, all the hypotheses of this study are proven to be acceptable since perceiving opportunities, feeling capable, having low levels of fear of failure, and knowing another entrepreneur increase the probability of becoming a social entrepreneur. In addition, these variables have the same relationship with becoming a nonsocial entrepreneur, although it is true that, if their OR is observed, it is seen that its influence does vary between entrepreneurs. Therefore, for example, a higher OR was obtained for social entrepreneurs for the variable of perception of opportunities (1.755 compared to 1.724$)$ and fear of failure (0.809 compared to 
0.695), while for the self-efficacy variable (4.551 compared to 2.075) and the socialization variable (2.161 compared to 1.900), the OR values were higher for nonsocial entrepreneurs.

Moreover, both types of entrepreneurs can also be differentiated if the control variable results are compared. For example, it is a true that gender and education have the same relationship with the variable for both entrepreneurs, but the fact is that they differ with regard to age. It is specifically observed that while young individuals are the most likely to become nonsocial entrepreneurs (between 18 and 34 years OR 1.068 and 55 to 65 years OR 0.540), individuals of any age undertake social entrepreneurship equally. Another differentiating case is consequence of the level of development variable. In fact, it has been observed that as the level of development increases, the probability of the individual becoming a social entrepreneur decreases (0.651 developing countries and 0.501 developed countries), while this trend has not been observed for nonsocial entrepreneurs (1.084 developing countries and 0.541 developed countries).

\section{Conclusions}

The lack of consensus regarding the conceptualization of the field of study and the insufficient progress made at the quantitative level are both art of the main problems in social entrepreneurship. Most papers have used qualitative methodologies or are based on stories of successful entrepreneurs. The inability to generalize these types of results has produced slow progress in scientific matters. This study contributes to solving this gap when analyzing the variables that influence the individual at the time of undertaking entrepreneurship, using a sample of 59 countries. This has enabled us not only to know the social entrepreneur's profile but also to compare it with the nonsocial entrepreneur's.

The main conclusions are that the profiles of both entrepreneurs differ, although they have some similarities. Therefore, for example, it can be said that the nonsocial entrepreneur 
is a young male, who has studied at university, who is most likely operating in a developing country, who perceives opportunities, who feels capable, who is not afraid of failure and who knows another entrepreneur. While the social entrepreneur is a male, who has studied at university, who is conditioned by the level of development to start his business, who is more likely to undertake entrepreneurship as the level of development decreases, who perceives opportunities, who feels capable, who is not afraid of failure and who knows another entrepreneur.

Thus, with the control variables, it was observed that both for the nonsocial entrepreneur and the social entrepreneur, it is men who to a greater extent create enterprises. This was expected for the nonsocial entrepreneur since the literature indicates that it is mainly men who create enterprises with mainly economic objectives, whereas for social enterprises, there are several authors who state that women feel closer to social objectives due to the stereotypes related to this group, and therefore, they would be the ones that to a greater extent would create this type of enterprise (Eagly 1987; Connell 1990; Van Ryzin et al. 2009; Hechavarría et al. 2012; Nicolás and Rubio 2016). However, the data do not confirm what is indicated by the literature, observing that men are more likely to create both social and nonsocial enterprises.

Regarding age, it is proven that young people create nonsocial enterprises to a greater extent, as the literature indicates. However, in the case of the social entrepreneur, there is no significant relationship between age and the initiation of an enterprise, which indicates that individuals of any age equally undertake social enterprises. This fact can be explained by what is stated in the literature, where there is no consensus on the age at which individuals usually undertake social enterprises. Thus, on the one hand, Hoogendoorn and Hartog (2010) state that the young population places greater value on nonmaterialistic goals, such as personal development, personal expression and the desire for meaningful work that does not 
imply a materialistic nature (Inglehart 1981; 1997; 2000), understanding that young people will be the ones who will more likely undertake social enterprises. Johnson's (2003) work is based on the same premise, but this study, using a sample of Canadian individuals, finally concludes that it is older people, with long work experience, who become social entrepreneurs to a greater extent. On the other hand, Putnam (2000) or Piotrowski and Van Ryzing (2007) believe that, in fact, older individuals are the ones who are more socially committed. Therefore, with the results of this research, the open debate in the literature can be ended, and the conclusion that social undertakings are not conditioned by the age of the individual can be confirmed.

Regarding education level, it is confirmed that it is mainly people with university studies who undertake both social and nonsocial enterprises to a greater extent. However, it is observed that, regarding social enterprises, a university education is more influential (as shown by their OR). The literature justifies these results because it states that, for social enterprises, having a high level of education can help manage the greater complexity surrounding a social business idea (Levie et al. 2006; Neck et al. 2009; Van Ryzin et al. 2009; Dacin et al. 2011). At this point, it cannot be ignored that these companies are created to solve neglected social problems and, therefore, are often located in difficult or complicated markets or geographical areas (Di Domenico et al. 2010). Hence, they have to face a greater number of challenges and problems regarding managing their business since, for example, their customers may not be able to pay for the good or the service offered to them. (Levie et al. 2006). On the other hand, nonsocial entrepreneurs tend to avoid environments such as those that the social entrepreneur usually encounters since their main objective is to generate their own economic benefits (Di Domenico et al. 2010).

Finally, to conclude with the control variables, it is confirmed that the level of economic development in a country has an influence when individuals decide to create both a 
social and nonsocial enterprise, although the influences act in dissimilar ways. In particular, the existence of a clear tendency for social enterprises has been observed. In particular, as the level of development in a country decreases, the probability of the individual undertaking a social enterprise increases. On the other hand, this fact has not been observed for nonsocial enterprises, where the probability of undertaking the enterprise is greater in developing countries. This fact is based on the arguments of authors who understand that the extreme situations of economic and institutional development do not favor the creation of nonsocial enterprises, which is the case in underdeveloped and developed countries (Wennekers et al. 2005; Acs 2006; Acs et al. 2008, Aidis et al. 2010). Specifically, these authors indicate that in developing countries there is a more favorable environment for individual deciding to undertake nonsocial enterprises since the competition that an entrepreneur can find is not as high as in developed countries. In addition, there is greater economic stability and greater institutional development than in underdeveloped countries (Wennekers et al. 2005; Acs 2006; Acs et al. 2008). However, as stated in the literature, the social entrepreneur does not support that philosophy when creating his company. Specifically, it must be taken into account that, unlike the nonsocial entrepreneur, the business opportunities of social entrepreneurs are social problems neglected by institutions (Levie y Autio 2011). Thus, it is logical to think that the lower the level of economic development of the country, the less money they will have, and their institutions will invest in eradicating existing social problems. Therefore, there will be more social problems, which means that there will be many business opportunities for these entrepreneurs. Hence, it is not strange to find statements such as that by Neck et al. (2009) who state that, in less developed countries, rather than detecting opportunities, social entrepreneurs need skills to decide which problems are the most urgent after observing the different problems that affect and surround them. 
In addition, the study results also show that all the subjective variables have a significant influence on social and nonsocial entrepreneurs, but the intensity of their influence is different. Responding to the first hypothesis presented in this paper, the perception of opportunities specifically has a positive influence when creating social and nonsocial enterprises. This would explain what is discussed in the literature, indicating that although social problems are observed by everyone, only those who perceive them as business opportunities will become social entrepreneurs, and others will not (Neck et al. 2009).

Regarding the second hypothesis that this research tests, it is confirmed that, for social entrepreneurs, the perception of their own abilities when undertaking enterprises in all the types of countries analyzed is determinant. Therefore, as indicated by the literature, feeling that one has the required skills to start and run a business helps the individual to decide to undertake an enterprise (Boyd and Vozikis 1994). Moreover, it is the most relevant variable for both models, although it is more important in the case of nonsocial entrepreneurs. The individual who wants to start a business to achieve his own benefit is obviously required to feel capable of carrying out that project (Bandura 1997). In the case of social entrepreneurship, the truth is that the need to address the social problem that led him to start the business may be a reason for the individual not to question himself to a large extent about whether he/she has the knowledge and skills required to undertake a social enterprise, as he/she is more concerned with the importance of action, that is, solving the problem (Langowitz y Minniti 2007).

Regarding the third hypothesis, it is observed that the fear of failure variable is associated negatively with the decision to become both a social and nonsocial entrepreneur. The results are consistent with the literature, suggesting that an individual's risk perception reduces business incentives, as the perception of failure increases (Arenius and Minniti 2005; Bojica et al. 2012). When an entrepreneur decides to start a business, he/she analyzes the risk 
associated with his business, i.e., the perceived probability of receiving benefits and the consequences associated with failure. All these factors will vary depending on whether they are considering starting a social enterprise, as social entrepreneurs create their businesses with the mission of solving neglected social problems. For this reason, they often locate their companies in markets that do not work as well as those of other companies (Di Domenico et al. 2010), so it seems that fear does not prevent them from achieving their vision; they simply manage it in order to solve the social problem that led them to start the business activity (Dees 2001).

Finally, it is also possible to state that knowing another entrepreneur has a positive influence when an individual decides to create an enterprise; and this is truer for social enterprises than for nonsocial enterprises. Thus, it can be stated that individuals who have been able to observe and learn attitudes from an entrepreneur are more likely to become social entrepreneurs (Formichella 2004).

Therefore, coinciding with the literature, the results show that socialization, perceived opportunities and self-efficacy are positively associated with the decision to become an entrepreneur, both for social and nonsocial entrepreneurs, whereas fear of failure has a negative association. Self-efficacy emerges as the most important component of the decision to start a new nonsocial enterprise, coinciding with the findings of previous studies (Arenius and Minniti 2005; Baron 2004), followed by knowing another entrepreneur and perceiving business opportunities.

The results of this study have potentially significant implications, showing differences between both types of entrepreneurs with regard to age, education level, the influence of economic development, and the intensity of the influence of gender, self-efficacy, perception of opportunities, fear of failure and socialization variables. 
This study, like any other, is not exempt from limitations. In particular, this research analyzes data derived from a survey conducted in 2015, so this study has been conducted with a cross-sectional design, which makes it impossible to examine the relationships between the variables over time. It must be recognized that the factors listed condition the initiation of social enterprises in this year, and probably in the coming years, but the passage of time can also cause some of these variables or new ones that are not considered in the present study to decrease in importance.

For researchers, there are many lines for future research on the social entrepreneur. For an in-depth study, it would be interesting to further examine gender and education levels, as the results obtained in the literature are contradictory. Moreover, given the unique features of social entrepreneurs, it would be interesting to analyze the levels of persistence, creativity, leadership or social relationships, among others.

Finally, it should be noted that this study contributes to the scarce literature on social entrepreneurship by analyzing the social entrepreneur through an empirical study by which it is possible to generalize the results obtained. For this reason, this research is expected to promote knowledge about the creation of social enterprises in the scientific field, stimulating research on the issues that condition social entrepreneurship, as in the business world, where this type of entrepreneurship can be seen as another job opportunity for any individual.

\section{References}

Acs, Z. (2006). How Is Entrepreneurship Good for Economic Growth? Innovations: Technology, Governance, Globalization, 1(1), 97-107.

Acs, Z., \& Audretsch, D. (2001). The emergence of the entrepreneurial society. Swedish: Foundation for Small Business Review. 
Acs, Z., Boardman C., \& McNeely, C. L. (2013). The social value of productive entrepreneurship. Small Business Economics, 40(3), 785-796.

Acs, Z., Desai, S., \& Hessels, J. (2008). Entrepreneurship, economic development and institutions. Small Business Economics, 31(3), 219-234.

Aidis, R., Estrin, S., \& Mickiewicz, T. (2010). Institutions, finance and the level of development: the impact on entrepreneurship in transition. Review of Economics and Institutions, 1(1), 1-26.

Alvord, S. H., Brown, L. D., \& Letts, C. W. (2004). Social entrepreneurship and societal transformation, an exploratory study. The Journal of Applied Behavioral Science, 40(3), 260-282.

Arenius, P., \& Minniti, M. (2005). Perceptual variables and nascent entrepreneurship. Small Business Economic, 24(3), 223-247.

Austin, J., Stevenson, H., \& Wei-Skillern, J. (2006). Social and Commercial entrepreneurship: same, different, or both? Entrepreneurship Theory and Practice, 30(1), 1-22.

Bandura, A. (1997). La autoeficacia: El ejercicio del control. New York: WH Freeman.

Baron, R. (2004). The Cognitive Perspective: A Valuable Tool of Answering Entrepreneurship's Basic "Why" Questions. Journal of Business Venturing, 19(2), 221-240.

Begley, T., \& Boyd, D. (1987). Psychological Characteristics Associated with Performance in Entrepreneurial Firms and Small Businesses. Journal of Business Venturing, 2(1), 79-93.

Berger, P., \& Luckman, T. (1984). La construcción social de la realidad. Buenos Aires: Amorrortu.

Bojica, A. M., Ruiz, M., \& Fuentes, M. M. (2012). La adquisición de conocimiento a través de relaciones interorganizativas y la orientación emprendedora: el papel mediador del capital social de segundo orden. Cuadernos de Economía y Dirección de la Empresa, 15(3), 141-153.

Bornstein, D. (1998). Changing the world on a shoestring. Atlantic Monthly, 281(1), 34-38.

Bornstein, D. (2004). How to change the world: Social entrepreneurs and the power of new ideas. UK: Oxford University Press. 
Bornstein, D., \& Davis, S. (2010). Social Entrepreneurship. What everyone needs to know. UK: Oxford University Press.

Boschee, J. (1998). Merging Mission and Money: A board member's guide to social entrepreneurship, National Center for nonprofit boards. http://www.socialent.org/pdfs/MergingMission.pdf

Boschee, J., \& McClurg, J. (2003). Toward a better understanding of social entrepreneurship: some important distinctions. http://www.se-alliance.org/better_understanding.pdf.

Boyd, N.G., \& Vozikis, G.S. (1994). The influence of self-efficacy on the development of entrepreneurial intentions and actions. Entrepreneurship Theory and Practice, 18(4), 64-77.

Bridet, E., Eum, H., \& Ryu, J. (2018). Diversity of Social Enterprise Models in South Korea. Voluntas: International Journal of Voluntary and Nonprofit Organizations. https://doi.org/10.1007/s11266018-9951-8

Brockhaus, R. H. (1982). The psychology of the entrepreneur. In C. A. Kent, D. L. Sexton, \& K. G. Vesper (Eds.), The Encyclopedia of Entrepreneurship. University of Illinois at UrbanaChampaign's Academy for Entrepreneurial Leadership Historical Research Reference in Entrepreneurship. https://ssrn.com/abstract=1496225

Brouard, F., \& Larivet, S. (2010). Essay of clarifications and definitions of the related concepts of social enterprise, social entrepreneur and social entrepreneurship. In A. Fayolle, \& H. Matlay (Eds.), Handbook of research on social entrepreneurship (pp. 29-56). UK: Edward Elgar Ed.

Cantillon, R. (1755). Essay on the Nature of Trade in General. London: Henry Higgs.

Chell, E, Spence, L. J., Perrini, F., \& Harris, J. D. (2016). Social Entreprenurship and Business Ethics: Does Social Equal Ethical? Journal of Business Ethics, 133(4), 619-625.

Chen, H. M., Muramoto, K., Yamauchi, F., Fujimoto, K., \& Nokihara, K. (1998). Antioxidative properties of histidine-containing peptides designed from peptide fragments found in the digests of a soybean protein. Journal of Agricultural and Food Chemistry, 46(1), 49-53. 
Connell, R. W. (1990). An iron man: The body and some contradictions of hegemonic masculinity, In M. Messner, \& D. Sabo (Eds.), Sport, men and the gender order (pp. 141-149). Champaign, IL: Human Kinetics Books.

Cornelius, N., Todres, M., Janjuha-Jivraj, J., Woods, A., \& Wallace, J. (2008). Corporate Social Responsibility and the Social Enterprise. Journal of Business Ethics, 81, 355-370.

Dacin, M. T., Dacin, P. A., \& Tracey, P. (2011). Social entrepreneurship: a critique and future directions. Organization Science, 22(5), 1203-1213.

De Castro, J. O., Justo, R., \& Olivares, A. M. (2008). La naturaleza del proceso emprendedor en España en el contexto internacional. España: Fundación BBVA.

Dees, J. G. (1998). Enterprising nonprofits: What do you do when traditional sources of funding fall short? Harvard Business Review, 76, 55-67.

Dees, J. G. (2001). The Meaning of social entrepreneurship. http://communitywealth.org/content/meaning-social-entrepreneurship

Dees, J. G. (2012). A tale of two cultures: Charity, problem solving, and the future of social entrepreneurship. Journal of Business Ethics, 111(3), 321-334.

De la Rosa Acosta, B. (1986). Educación social y profesionalización pedagógica. Cuestiones pedagógicas: Revista de Ciencias de la Educación, 3, 65-72.

Diochon, M., \& Ghore, Y. (2016). Contextualizing a social enterprise opportunity process in an emerging market. Social Enterprise Journal, 12(2), 107-130.

Di Domenico, M. L., Haugh, H., \& Tracy, P. (2010). Social Bricolage: Theorizing social value creation in social enterprises. Entrepreneurship Theory and Practice, 34(4), 681-703.

Drucker, P. F. (1989): The new realities in government and politics, in Economics and Business, in Society and World View. New York: HarperBusiness.

Eagly, A. (1987). Sex differences in social behavior: A social-role interpretation. Hillsdale, NJ: Erlbaum. 
Formichella, M. M. (2004). El concepto de emprendimiento y su relación con la educación, el empleo y el desarrollo local. Argentina: Tres Arroyos.

García, C., Martínez, A., \& Fernández, R. (2010). Características del emprendedor influyentes en el proceso de creación empresarial y en el éxito esperado. Revista Europea de Dirección y Economía de la Empresa, 19(2), 31-48.

Grusec, J. E., \& Hastings, P. D. (Eds.). (2014). Handbook of socialization: Theory and research. New York: Guilford Publications.

Hair, J., Anderson, R., Tatham, R., \& Black. W. (1998). Multivariate data analysis. New York: Prentice Hall College Div.

Hechavarría, D. M., Ingram, A., Justo, R., \& Terjesen, S. (2012). Are women more likely to pursue social and environmental entrepreneurship? In K. D. Hughes \& J. E. Jennings (Eds.) Global women’s entrepreneurship research: Diverse settings, questions and approaches (pp. 135-151). Cheltenham/Northampton: Edward Elgar.

Hibbert, S., Hogg, G., \& Quinn, T. (2005). Social entrepreneurship: Understanding consumer motives for buying The Big Issue. Journal of Consumer Behaviour, 4(3), 159-172.

Hindle, K. (2006). A measurement framework for international entrepreneurship policy research: From impossible index to malleable matrix. International Journal of Entrepreneurship and Small Business, 3(2), 139-182.

Hockerts, K. (2015). The Social Entrepreneurial Antecedents Scale (SEAS): a validation study. Social Enterprise Journal, 11(3), 260-280.

Hornaday, J. A., \& Aboud, J. (1971). Characteristics of successful entrepreneurs. Personnel Psychology, 24(2), 141-153.

Hoogendoorn, B., \& Hartog, C. M. (2010). Prevalence And Determinants Of Social Entrepreneurship At The Macro-Level Scales report No. H201022. EIM: Zoetermeer. 
Inglehart, R. (1981). Post-Materialism in a environment of insecurity. American Political Science Review, 81, 1289-1303.

Inglehart, R. (1997). Modernization and postmodernization: Cultural, economic, and political change in 43 societies. NJ: Princeton University Press.

Inglehart, R. (2000). Globalization and Postmodern Values. The Washington Quarterly, 23(1), 215-228. Johnson, S. (2003). Social Entrepreneurship Literature Review. New Academy Review, 2(2), 42-56.

Jiménez, A., Palmero-Cámara, C., González-Santos, M. J., González-Bernal, J., \& Jiménez-Eguizábal, J. A. (2015). The impact of educational levels on formal and informal entrepreneurship. Business Research Quarterly, 18, 204-212.

Kerlinger, F. N. (2002). Investigación del comportamiento. México: McGraw-Hill.

Kerlin, J. A. (2006). Social Enterprise in the United States and Europe: Understanding and Learning from the Differences. Voluntas: International Journal of Voluntary and Nonprofit Organizations, 17, 247-263.

Kerlin, J. A. (2010). A comparative analysis of the global emergence of social enterprise. Voluntas: International Journal of Voluntary and Nonprofit Organizations, 21, 162-179.

Knight, F. H. (1921). Risk. Uncertainty and Profit. New York: Hougthon Mifflin.

Kistruck, G. M., \& Beamish, P. W. (2010). The interplay of form, structure, and embeddedness in social intrapreneurship. Entrepreneurship Theory and Practice, 34(4), 735-761.

Kirzner, I. (1973). Competition and entrepreneurship. Chicago: The University of Chicago Press.

Korosec, R. L., \& Berman, E. M. (2006). Municipal support for social entrepreneurship. Public Administration Review, 66(3), 448-462.

Langowitz, N., \& Minniti, M. (2007). The Entrepreneurial Propensity of Women. Entrepreneurship Theory and Practice, 31(3), 341-364.

Leadbeater, C. 1997. The rise of the social entrepreneur. London: Demos. 
Levie, J., \& Autio, E. (2011). Regulatory burden, rule of law, and entry of strategic entrepreneurs: An international panel study. Journal of Management Studies, 48(6), 1392-1419.

Levie, J., Brooksbank, D., Jones-Evans, D., Harding, R., \& Hart, M. (2006). Measuring Social Entrepreneurship: Lessons from Three Years of Experimentation by the UK Global Entrepreneurship Monitor Team (Interactive Paper). Frontiers of Entrepreneurship Research, 26(25), 3. https://digitalknowledge.babson.edu/fer/vol26/iss25/3/

Light, P. C. (2006). Reshaping Social Entrepreneurship. Stanford Social Innovation Review, 45-51.

Light, I. H., \& Rosenstein, C. N. (1995). Race, ethnicity, and entrepreneurship in urban America. New York: Transaction Publishers.

Lumpkin, G. T. (2011). From legitimacy to impact: Moving the field forward by asking how entrepreneurship informs life. Strategic Entrepreneurship Journal, 5(1), 3-9.

Mair, J., \& Martí, I. (2006). Social entrepreneurship research: a source of explanation, prediction, and delight. Journal of World Business, 41(1), 36-44.

Mazzei, M., \& Roy, M. J. (2017). From Policy to Practice: Exploring Practitioners’ Perspectives on Social Enterprise Policy Claims. Voluntas: International Journal of Voluntary and Nonprofit Organizations, 28, 2449-2468.

McClelland, D. C. (1961). The achieving society. Van Nostrand: Princeton.

McClelland, D. C. (1987). Human motivation. Scott Foresman: Glenview.

Meyskens, M., Robb-Post, C., Stamp, J. A., Carsrud, A. L., \& Reynolds, P. D. (2010). Social ventures from a resource-based perspective: an exploratory study assessing global Ashoka fellows. Entrepreneurship Theory and Practice, 34(4), 661-680.

Morris, M.H. (1998). Entrepreneurial Intensity: Sustainable Advantages for Individuals, Organizations and Societies, Westport. CT: Quorum.

Mort, G. Weerawardena, J., \& Carnegie, K. (2003). Social entrepreneurship: Towards conceptualization. International Journal of Nonprofit and Voluntary Sector Marketing, 8(1), 76-88. 
Mueller, S. L., \& Thomas, A. S. (2001). Culture and entrepreneurial potential: A nine country study of locus of control and innovativeness. Journal of Business Venturing, 16(1), 51-75.

Murphy, P. J., \& Coombes, S. M. (2009). A Model of social entrepreneurial Discovery. Journal of Business Ethics, 87(3), 325-336.

Neck, H., Brush, C., \& Allen, E. (2009). The landscape of social entrepreneurship. Business Horizons, 52(1), 13-19.

Nicolás, C., \& Rubio, A. 2016. Social enterprise: Gender gap and economic development. European Journal of Management and Business Economics, 25, 56-62.

Nicolás, C., Rubio, A. \& Fernández-Laviada, A. (2018). Cognitive Determinants of Social Entrepreneurship: Variations According to the Degree of Economic Development, Journal of Social Entrepreneurship, 9(2),154-168.

Nissan, E., Castaño, M. S., \& Carrasco, I. (2012). Drivers of non-profit activity: a cross-country analysis. Small Business Economic, 38, 303-320.

Oetting, E. R., \& Donnermeyer, J. F. (1998). Primary socialization theory: The etiology of drug use and deviance. I. Substance Use \& Misuse, 33(4), 995-1026.

Parker, S. C. (2009). The Economics of Entrepreneurship. UK: Cambridge University Press.

Peredo, A. M., \& Chrisman, J. J. (2006). Toward a Theory of Community-Based Enterprise. Academy of Management Review, 31(2), 309-328.

Peredo, A. M., \& McLean, M. (2006). Social entrepreneurship: A critical review of the concept. Journal of World Business, 41, 56-65.

Peterman, N. E., \& Kennedy, J. (2003). Enterprise education: Influencing students’ perceptions of entrepreneurship. Entrepreneurship Theory and Practice, 28(2), 129-144.

Piotrowski, S. J., \& Van Ryzing, G. G. (2007). Citizen attitudes toward transparency in local government. American Review of Public Administration, 37(3), 306-323. 
Pless, N. M. (2012). Social entrepreneurship in theory and practice-An introduction. Journal of Business Ethics, 111(3), 317-320.

Putnam, R. P. (2000). Bowling Alone: The Collapse and Revival of American Community. New York: Simon and Schuster.

Rey-Martí, A., Ribeiro-Soriano, D., \& Palacios-Marqués, D. (2016). A bibliometric analysis of social entrepreneurship. Journal of Business Research, 69(5), 1651-1655.

Reynolds, P. D., Bosma, N., Autio, E., Hunt, S., De Bono, N., Servais, I., López-García, P., \& Chin, N. (2005). Global Entrepreneurship Monitor: data collection design and implementation 1998-2003. Small Business Economic, 24(3), 443-456.

Ripollés, M., \& Blesa, A. (2006). Redes personales del empresario y orientación emprendedora en las nuevas empresas. Cuadernos de Economía y Dirección de Empresas, 26, 73-94.

Rivera-Santos, M., Holt, D., Littlewood, D., \& Kolk, A. (2015). Social entrepreneurship in sub-Saharan Africa. The Academy of Management Perspective, 29(1), 72-91.

Santos, F. M. (2012). A positive theory of social entrepreneurship. Journal of Business Ethics, 111(3), 335-351.

Sassmannshausen S. P., \& Volkmann, C. (2018). The Scientometrics of Social Entrepreneurship and Its Establishment as an Academic Field. Journal of Small Business Management, 56(2), 251-273

Say, J. B. 1803. Tratado de Política Económica. Mexico: Fondo de Cultura Económica.

Schumpeter, J. 1934. Theory of Economic Development. Cambridge: Harvard University Press.

Seelos, C., \& Mair, J. (2007). Profitable Business Models and Market Creation in the Context of Deep Poverty: A Strategic View. Academy of Management Perspectives, 21(4), 49-63.

Shane, S., \& Venkataraman, S. (2000). The promise of entrepreneurship as a field of research. Academy of Management Review, 25(1), 217-226.

Sharir, M., \& Lerner, M. (2006). Gauging the success of social ventures initiated by individual social entrepreneurs. Journal of World Business, 41, 6-20. 
Sharma, P., \& Chrisman, J. J. (1999). Toward a reconciliation of the definitional issues in the field of corporate entrepreneurship. Entrepreneurship Theory and Practice, 24, 11-27.

Shaw, E., \& Carter, S. (2007). Social entrepreneurship. Theoretical antecedents and empirical analysis of entrepreneurial processes and outcomes. Journal of Small Business and Enterprise Development, 14(3), 418-434.

Short, J. C., Moss, T. W., \& Lumpkin, G. T. (2009). Research in social entrepreneurship: past contributions and future opportunities. Strategic Entrepreneurship Journal, 3(2), 161-194.

Singer, S., Amorós, J. E., \& Moska, D. (2015). Global Entrepreneurship Monitor 2014, Executive Report. Global Entrepreneurship Research Association. http://www.gemconsortium.org/

Solomon, G. T., \& Winslow, E. K. (1988). Toward a descriptive profile of the entrepreneur. The Journal of Creative Behavior, 22(3), 162-171.

Starr, J. A., \& Fondas, N. (1992). A model of entrepreneurial socialization and organization formation. Entrepreneurship Theory and Practice, 17(1), 67-76.

Stevenson, H. H., Roberts, M. J., \& Grous-beck, H. I. (1989). New Business Ventures and the Entrepreneur. IL: Irwin.

Stevenson, H. H. (2000). Why the entrepreneurship has won! Coleman White Paper. http://www.unm.edu/ asalazar/Kauffman/Entrep_research/e_won.pdf

Terjesen, S., Bosma, N. S., \& Stam, E. (2016). Advancing public policy for high growth, female, and social entrepreneurs. Public Administration Review, 76(2), 230-239.

Thompson, J. L., Alvy, G., \& Lees, A. (2000). Social entrepreneurship-a new look at the people and the potential. Management Decision, 38(5), 328-338.

Timmons, J. A. (1978). Characteristics and role demands of entrepreneurship. American Journal of Small Business, 3(1), 5-17. 
Van Ryzin, G. G., Grossman, S., DiPadova-Stocks, L., \& Bergrud, E. (2009). Portrait of the Social Entrepreneur: Statistical Evidence from a US Panel. Voluntas: International Journal of Voluntary and Nonprofit Organizations, 20, 129-140.

Weerawardena, J., \& Mort, G. (2006). Investigating social entrepreneurship: A multidimensional model. Journal of World Business, 41(1), 21-35.

Wennekers, S., Van Wennekers, A., Thurik, R., \& Reynolds, P. (2005). Nascent entrepreneurship and the level of economic development. Small Business Economics, 24(3), 293-309.

Zahra, S. A., Gedajlovic, E., Neubaum, D. O., \& Shulman, J. M. (2009). A typology of social entrepreneurs: Motives, search processes and ethical challenges. Journal of Business Venturing, 24(5), 519-532.

Zander, I. (2004). El espíritu emprendedor en el ámbito geográfico. Fundamentos conceptuales e implicaciones para la formación de nuevos clusters. Cuadernos de Economía y Dirección de la Empresa, 20, 9-34.

Zebeda, S. (2012). Characteristics of the Social Entrepreneur: A Neoclassical Perspective. Netherlands: Erasmus University Rotterdam. 